\title{
Genetic diversity of eucalypts for germplasm conservation in Forest Area with the Special Purpose of Mount Bromo, Karanganyar, Indonesia
}

\author{
RAHAYU $^{1, \bullet}$, FATIMAH ${ }^{2}$, JAMAL WIWOHO ${ }^{3}$, SUNNY UMMUL FIRDAUS ${ }^{3}$, PUJIYONO $^{3}$, MARIMIN ${ }^{4}$, \\ DWI PRIYO ARIANTO' ${ }^{1}$, AHMAD PRAMONO ${ }^{1}$ \\ ${ }^{1}$ Faculty of Agriculture, Universitas Sebelas Maret. Jl. Ir. Sutami 36A, Surakarta 57126, Central Java, Indonesia. Tel./fax. +62-271-663375, \\ vemail: rahayu@uns.ac.id \\ ${ }^{2}$ Indonesian Center of Biotechnology and Genetic Resources, Ministry of Agriculture. Jl. Tentara Pelajar 3A, Bogor 16111, West Java, Indonesia \\ ${ }^{3}$ Faculty of Law, Universitas Sebelas Maret. Jl. Ir. Sutami 36A Surakarta 57126, Central Java, Indonesia \\ ${ }^{4}$ Faculty of Cultural Studies, Universitas Sebelas Maret. J1. Ir. Sutami 36A Surakarta 57126, Central Java, Indonesia
}

Manuscript received: 13 July 2021. Revision accepted: 19 September 2021.

\begin{abstract}
Rahayu, Fatimah, Wiwoho J, Firdaus SU, Pujiyono, Marimin, Arianto DP, Pramono A. 2021. Genetic diversity of eucalypts for germplasm conservation in Forest Area with the Special Purpose of Mount Bromo, Karanganyar, Indonesia. Biodiversitas 22: 42234235. As a repository of a gene pool, eucalypts germplasm enriches biodiversity, maintains ecosystem sustainability, and aids in conservation. Therefore, this study aims to analyze the genetic diversity of eucalypts (Corymbia and Eucalyptus) for the development of germplasm conservation in Forest Area with the Special Purpose (KHDTK) Bromo Forest, Karanganyar, Indonesia. In this study, 14 simple sequence repeat (SSR) markers were used to assess the genetic diversity among 20 accessions (Corymbia and 5 Eucalyptus species) from Central and West Java. Subsequently, the genetic parameters were measured and a phylogenetic tree was constructed. The result showed that the SSR markers have high variability, although they belong to different genera. Furthermore, the genetic diversity showed 49 alleles with an average of 3 alleles per locus, while the polymorphism information content (PIC) values were 0.55 . There were 4 SSR markers (EMBRA13, EMBRA8, EMCRC11, and EMBRA2) with high PIC value, while the gene diversity (He) of Corymbia and 5 Eucalyptus showed a low level of genetic diversity. The genetic relationship and population structure were divided into genera Corymbia and Eucalyptus. For further application, the eucalypt cultivated in the KHDTK Bromo Forest can contribute as a reference set and 14 SSR markers as a potential marker in combination with morphological characterization to generate a database for germplasm management and conservation.
\end{abstract}

Keywords: Corymbia citriodora, Eucalyptus deglupta, E. globulus, E. pellita, E. urophylla, simple sequence repeat

\section{INTRODUCTION}

Eucalypts is one of the most important industrial forest plantations due to their rapid growth capacity, wider adaptability, and versatile purposes such as pulp, paper, timber, and eucalypt oil production (Sumathi and Yasodha, 2014). Eucalypt belongs to the Myrtaceae family and comprises over 800 species, including 3 closely related genera, namely Angophora, Corymbia, and Eucalyptus (Nicolle 2019). The genus of Angophora consists of only one genus commonly present in New South Wales and Queensland, Australia (Nicolle 2019). Meanwhile, the 2 subgenera of Corymbia (bloodwoods) include Corymbia citriodora which belongs to the Blakella subgenus (Nicolle 2019). The natural distribution of Corymbia extended to northern or eastern Australia (Schuster et al. 2019; Goodine and Oelgemoller 2020). Out of the 9 subgenus of Eucalyptus, Eucalyptus urophylla, E. globulus, E. deglupta, and E. pellita belong to the same subgenus namely Symphyomyrtus (Nicolle, 2019). Similarly, the natural distribution of Eucalyptus species is mostly present in Australia and partly in Papua New Guinea, while E. deglupta Blume and E. urophylla S.T. Blake are the only two species spread in Eastern Indonesia (Nicolle 2019).

Plant genetic resources (PGR) need to be continuously enriched, conserved and maintained. Meanwhile, the strategy for preserving of eucalypts germplasm was carried out for ex-situ conservation in Forest Area with the Special Purpose (Kawasan Hutan Dengan Tujuan Khusus, KHDTK) Bromo Forest of Sebelas Maret University, Central Java Province. In forest management, the main focus is for the benefit of forestry research, development, and education (Apriyanto and Kusnandar 2020; Wicaksono et al. 2020). Moreover, the advancement of molecular genetic techniques is becoming increasingly important for studying biodiversity and nature conservation. Molecular tools are also used to decipher distributions and affiliation of a population distribution to identify the populations with immediate conservation concerns (Mukherjee and Ramakrishnan 2018).

Microsatellite or simple sequence repeat (SSR) is a DNA marker with a simple sequence consisting of one to six repeated bases, it is commonly present in plant genomes (Brondani et al. 1998). Meanwhile, the high level of polymorphism makes the SSR markers be distributed genetically based on species and individuals (Burke and Long 2012). The characteristics of SSR include the 
predominant distribution in genome, locus specificity, codominance, multi-allelic, high mutation rate, heterozygous, transferability across species, and associated with the gene expression and function (Sumathi and Yasodha 2014). However, the disadvantage of SSR markers in the genetic analysis is size homoplasy and a high polymorphism rate (Hodel et al. 2016). Therefore, phylogenetic studies need to be carried out with caution for distantly related species (Abdurakhmonov 2016). The quick examination of SSR with low cost and technical efficiency makes it preferable and attractive to be applied in the large practice of molecular analyses.

Previous studies on eucalypt using SSR markers include the development of SSR markers (Grattapaglia et al. 2015), genetic diversity (Liu et al. 2018b), population structure analyses (Costa et al. 2017), genetic linkage map (Sumathi et al. 2018), phenotypic and genotypic variation (Padovan et al. 2017; Zhou et al. 2020), and hybrid purity assessment (Subashini et al. 2014). However, in Indonesia, there are limited information and studies on the characterization of eucalypts germplasm based on SSR markers such as the genetic diversity of E. urophylla from 7 islands in eastern Indonesia (Payn et al. 2007) and genetic variation of $E$. deglupta, E. urophylla, and E. pellita from arboretum in Yogyakarta as well as seed garden in South Kalimantan (Nurtjahjaningsih et al. 2013).

Therefore, there is a need to have new insights about the distribution and genetic diversity of eucalypt in Indonesia for more comprehensive examination using the molecular technique. Meanwhile, this is the first study in KHDTK Bromo Forest to measure the genetic diversity of Corymbia and Eucalyptus as a preliminary study for the development of eucalypts germplasm conservation.

\section{MATERIALS AND METHODS}

\section{Plant materials}

The leaves of Corymbia and Eucalyptus used for DNA analysis were from a seedling at several locations in Central and West Java, Indonesia collected in 2021 (Figure 1, Table 1). These plants were planted and cultivated in a Forest Area with the Special Purpose (KHDTK) Bromo Forest for germplasm conservation. Subsequently, each leaf sample was collected, placed in a plastic bag, and stored in a deep freezer $\left(-20^{\circ} \mathrm{C}\right)$ until DNA extraction.

\section{Procedures}

This molecular analysis was carried out in 2021 at the Molecular Biology Laboratory of Indonesian Center for Agricultural Biotechnology and Genetic Resources Research and Development (ICABIOGRAD), Bogor. The fresh leaf samples were weighed $100 \mathrm{mg}$ each and crushed using liquid nitrogen, while the DNA extraction was conducted using a modified CTAB method ( $\mathrm{Yu}$ 1994). Furthermore, the PCR reaction was carried out at $20 \mu \mathrm{L}$ volume, which contained a PCR buffer mix, $0.5 \mu \mathrm{M}$ primers, DNA (50 ng/ $\mu \mathrm{L})$, and 1 unit of Mytaq DNA polymerase. The PCR program used was initial denaturation at $94^{\circ} \mathrm{C}$ for $5 \mathrm{~min}, 35$ cycles of $94^{\circ} \mathrm{C}$ for $60 \mathrm{sec}$ (denaturation), $55^{\circ} \mathrm{C}$ for $60 \mathrm{sec}$ (annealing), and $72^{\circ} \mathrm{C}$ for $120 \mathrm{sec}$ (extension), while the final extension was at $72^{\circ} \mathrm{C}$ for 7 min and soaked at $4^{\circ} \mathrm{C}$. Subsequently, the PCR products were separated using $8 \%$ polyacrylamide gel electrophoresis and the DNA staining was conducted with ethidium bromide. The visualization of PCR products used a gene analyzer machine (BioRad). The 23 microsatellite markers used were developed from E. grandis, E. urophylla, E. globulus, E. pellita, and C. citriodora (Table 2). Meanwhile, out of 23 primers, 14 were used for further analysis.

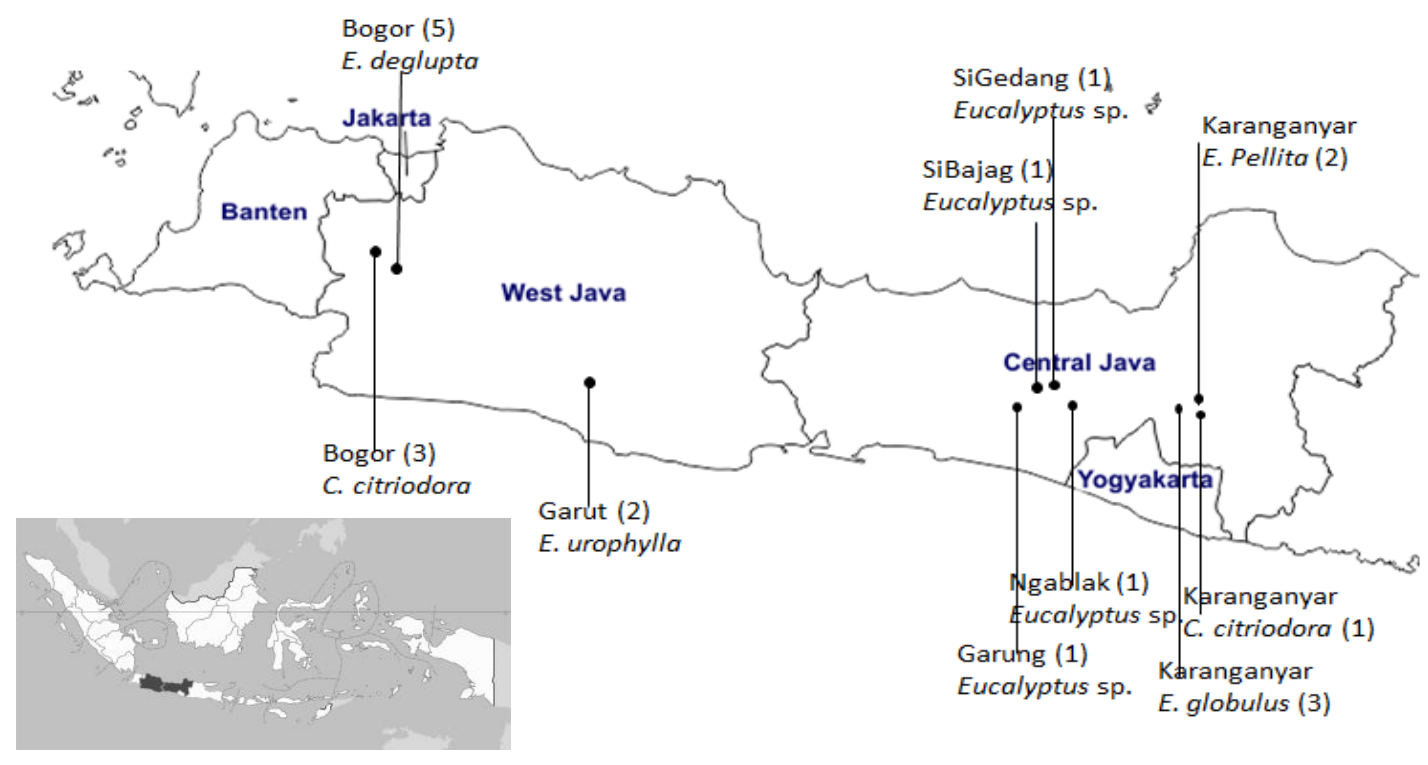

Figure 1. Map of West Java and Central Java, Indonesia, shows the location of eucalypt sampling sites collected from two provinces. The lines indicate the province and the number of eucalypts sampled from each location 
Table 1. Data of collected Corymbia and Eucalyptus used in this study

\begin{tabular}{|c|c|c|c|c|c|c|}
\hline Accession & Species & Local name & Natural distribution & Section & Source & Province \\
\hline E16 & Corymbia citriodora & $\begin{array}{l}\text { Ekaliptus } \\
\text { Lemon }\end{array}$ & Northern Australia & Maculatae & Karanganyar & Central Java \\
\hline E2 & C. citriodora & E. Lemon & Northern Australia & Maculatae & Bogor & West Java \\
\hline E6 & C. citriodora & E. Lemon & Northern Australia & Maculatae & Bogor & West Java \\
\hline E10 & C. citriodora & E. Lemon & Northern Australia & Maculatae & Bogor & West Java \\
\hline E221 & $\begin{array}{l}\text { Eucalyptus urophylla } \\
\text { S.T. Blake }\end{array}$ & Ampupu & $\begin{array}{l}\text { Wetar Islands, Timor, Alor, } \\
\text { Pantar, Lomblen, Adonara, } \\
\text { and Flores }\end{array}$ & Latoangulatae & Garut & West Java \\
\hline E222 & $\begin{array}{l}\text { E. urophylla S.T. } \\
\text { Blake }\end{array}$ & Ampupu & $\begin{array}{l}\text { Wetar Islands, Timor, Alor, } \\
\text { Pantar, Lomblen, Adonara, } \\
\text { and Flores }\end{array}$ & Latoangulatae & Garut & West Java \\
\hline E18 & E. deglupta Blume & $\begin{array}{l}\text { E. Pelangi } \\
\text { (Rainbow } \\
\text { Gum)/Leda }\end{array}$ & $\begin{array}{l}\text { West Papua, Seram, and } \\
\text { Sulawesi }\end{array}$ & Equatoria & Bogor & West Java \\
\hline E31 & E. deglupta Blume & $\begin{array}{l}\text { E. Pelangi } \\
\text { (Rainbow } \\
\text { Gum)/Leda }\end{array}$ & $\begin{array}{l}\text { West Papua, Seram, and } \\
\text { Sulawesi }\end{array}$ & Equatoria & Bogor & West Java \\
\hline E21 & E. deglupta Blume & $\begin{array}{l}\text { E. Pelangi } \\
\text { (Rainbow } \\
\text { Gum)/Leda }\end{array}$ & $\begin{array}{l}\text { West Papua, Seram, and } \\
\text { Sulawesi }\end{array}$ & Equatoria & Bogor & West Java \\
\hline E231 & E. deglupta Blume & $\begin{array}{l}\text { E. Pelangi } \\
\text { (Rainbow } \\
\text { Gum)/Leda }\end{array}$ & $\begin{array}{l}\text { West Papua, Seram, and } \\
\text { Sulawesi }\end{array}$ & Equatoria & Bogor & West Java \\
\hline E232 & E. deglupta Blume & $\begin{array}{l}\text { E. Pelangi } \\
\text { (Rainbow } \\
\text { Gum)/Leda }\end{array}$ & $\begin{array}{l}\text { West Papua, Seram, and } \\
\text { Sulawesi }\end{array}$ & Equatoria & Bogor & West Java \\
\hline E26 & Eucalyptus sp. & Ekaliptus & - & - & SiBajag & Central Java \\
\hline E25 & Eucalyptus sp. & Ekaliptus & - & - & Ngablak & Central Java \\
\hline E27 & Eucalyptus sp. & Ekaliptus & - & - & SiGedang & Central Java \\
\hline E24 & Eucalyptus sp. & Ekaliptus & - & - & Garung & Central Java \\
\hline E13 & $\begin{array}{l}\text { E. globulus subsp. } \\
\text { globulus Labill. }\end{array}$ & $\begin{array}{l}\text { E. globulus } \\
\text { (Tasmanian } \\
\text { Blue Gum) }\end{array}$ & $\begin{array}{l}\text { Native to southeast } \\
\text { Australia, originated in } \\
\text { Victoria and Tasmania and } \\
\text { the islands in the Bass Strait }\end{array}$ & Maidenaria & Karanganyar & Central Java \\
\hline E14 & $\begin{array}{l}\text { E. globulus subsp. } \\
\text { globulus Labill. }\end{array}$ & $\begin{array}{l}\text { E. globulus } \\
\text { (Tasmanian } \\
\text { Blue Gum) }\end{array}$ & $\begin{array}{l}\text { Native to southeast } \\
\text { Australia, originated in } \\
\text { Victoria and Tasmania and } \\
\text { the islands in the Bass Strait }\end{array}$ & Maidenaria & Karanganyar & Central Java \\
\hline E28 & $\begin{array}{l}\text { E. globulus subsp. } \\
\text { globulus Labill. }\end{array}$ & $\begin{array}{l}\text { E. globulus } \\
\text { (Tasmanian } \\
\text { Blue Gum) }\end{array}$ & $\begin{array}{l}\text { Native to southeast } \\
\text { Australia, originated in } \\
\text { Victoria and Tasmania and } \\
\text { the islands in the Bass Strait }\end{array}$ & Maidenaria & Karanganyar & Central Java \\
\hline E20 & E. pellita F. Muell & E. pellita & $\begin{array}{l}\text { West Papua, Papua New } \\
\text { Guinea, and northern } \\
\text { Australia }\end{array}$ & Latoangulatae & Karanganyar & Central Java \\
\hline E32 & E. pellita F. Muell & E. pellita & $\begin{array}{l}\text { West Papua, Papua New } \\
\text { Guinea, and northern } \\
\text { Australia }\end{array}$ & Latoangulatae & Karanganyar & Central Java \\
\hline
\end{tabular}

\section{Data analysis}

The amplified bands of the SSR data obtained were scored based on the allele sizes (bp) across multiple samples using PhotoCapMW. The species compatibility survey of SSR markers was classified into three categories, namely unamplified markers, amplified markers that produced 1 allele (monomorphic), and amplified markers with many alleles (polymorphic) (Nurtjahjaningsih et al. 2013). Meanwhile, the genetic parameters used to characterize microsatellite markers were genetic diversity per locus, the number of alleles detected $(\mathrm{N} a)$, observed heterozygosity $(\mathrm{Ho})$, expected heterozygosity $(\mathrm{H} e)$, and
Principal Coordinate Analysis (PCoA). These parameters were calculated to measure the genetic diversity between eucalypts species using PowerMarker v3.25 (Liu and Muse 2005) and GenAlex v6.41 (Peakall and Smouse 2006). Furthermore, the dendrogram was compiled from allele frequency data to describe the genetic relationship between eucalypts species and was analyzed using the NTSys v2.1 program (Rohlf 2005). The population structure of eucalypts was also analyzed using Structure v2.1 (Pritchard et al. 2000). The posterior probabilities were assessed as $K$ values between 1 and 10 using the Marcov Chain Monte Carlo method (MCMC). The parameter was used for the 
length of burning period $=10,000$, the iteration of MCMC after burning $=100,000$, with 5 replications. Also, the output of Ln P (D) as the estimated probability of $k$ and delta $k$ was calculated to assess the $k$ value, while the structure harvester program was used to estimate the main population (Earl and von Holdt 2012).

\section{RESULTS AND DISCUSSION}

\section{SSR amplified product}

Out of the 23 markers, the SSR markers amplification gave 4 unamplified (EMBRA1, EMBRA7, EMBRA19, and gSSR-GU023), 5 monomorphic, 3 e-SSR markers (eSSRGR046, eSSR-GR124, eSSR-GR127, gSSR-CA013, EMCRC49), and 14 polymorphic markers (Table 2). The comparison of genomic SSRs with e-SSR markers showed that the 3 e-SSR markers used displayed monomorphic in 1 Corymbia and 5 Eucalyptus species. This indicated that the e-SSR markers used have low levels of polymorphism for genomic markers. Subsequently, the 14 polymorphic markers were continued for genotyping analysis on all Corymbia and Eucalyptus accession (Table 3, Figure 2). In the characterization of the 14 markers, the amplification of SSR markers in Eucalyptus sp. and E. urophylla have the highest polymorphic markers compared to E. deglupta, E. globulus, and C. citriodora, which have a similar range of polymorphic markers, while $E$. pellita had the lowest polymorphic marker. From the number of amplified markers, the highest polymorphism rate of species compatibility of SSR markers was Eucalyptus sp.

\section{Genetic diversity of eucalypts}

Based on table 4, the parameters of genetic diversity per locus of eucalypts species showed that 49 alleles were detected with 3 as the average number of alleles per marker. C. citriodora had the highest number of alleles detected (Na: 1-4 alleles), while E. pellita had the lowest (Na: 1-2 alleles). Furthermore, E. urophylla, E. globulus, Eucalyptus sp., and E. deglupta had a similar number of alleles ( $\mathrm{N} a$ : $1-3$ alleles). The gene diversity ( $\mathrm{H} e$ ) value of Corymbia and 5 Eucalyptus species gave a low-level genetic diversity $(\mathrm{He}=0.00-0.66$, mean $\mathrm{He}=0.26)$. Meanwhile, the $\mathrm{He}$ value in E. urophylla ( $\mathrm{He}$ : 0.00-0.63, mean $\mathrm{He}=0.35$ ) and Eucalyptus sp. (He: 0.00-0.66, mean
$\mathrm{He}=0.42$ ) have the highest $\mathrm{He}$ value compared to $C$. citriodora $(\mathrm{He}$ : 0.00-0.66, mean $\mathrm{He}=0.24)$, E. deglupta ( $\mathrm{He}$ : 0.00-0.64, mean $\mathrm{He}=0.23)$ and E. globulus $(\mathrm{H} e$ : $0.00-0.61$, mean $\mathrm{H} e=0.27$ ) with similar range, while $E$. pellita has the lowest $\mathrm{H} e$ value $(\mathrm{H} e=0.00-0.50$, mean $\mathrm{H} e$ $=0.04)$. The value of heterozygosity $(\mathrm{Ho})$ per marker also has the same range in E. urophylla, E. globulus, E. pellita, and $C$. citriodora, ( $\mathrm{Ho}: 0.00-1.00)$ compared to the $\mathrm{Ho}$ value of Eucalyptus sp. (Ho: 0-0.75) and E. deglupta (Ho: 0-0.4). In this study, the $\mathrm{Ho}$ parameter indicated a wide range of heterozygosity in Corymbia and Eucalyptus (0.01.0, mean $\mathrm{Ho}=0.18$ ) (Table 4).

The PIC values ranged from 0.35 on the EMCRC41 marker to 0.69 on the EMBRA2 marker with an average of 0.55 . The 11 markers were very informative (PIC >0.5) with 4 markers having a PIC value >0.60, namely EMBRA13, EMBRA8, EMCRC11, and EMBRA2. Meanwhile, 7 out of 12 polymorphic markers in Eucalyptus sp. and 6 out of 8 polymorphic markers in C. citriodora have high inbreeding coefficient (Fis) values and significantly deviated from the Hardy-Weinberg equilibrium (HWE) law. Although a similar result was also shown in 3 out of the 7 polymorphic markers in $E$. deglupta, several polymorphic markers in E. urophylla did not significantly deviate from the HWE law (Table 4).

\section{Genetic relationships among eucalypts species}

The dendrogram of the UPGMA tree analysis showed that 20 Corymbia and Eucalyptus were grouped into two main clusters at a similarity coefficient of 0.59 (Figure 3 ). Cluster I consisted of 4 accessions of Corymbia ( $C$. citriodora) and Cluster II consisted of 16 accessions from 5 Eucalyptus species. Meanwhile, Cluster II is divided into two sub-clusters, namely sub-cluster IIA and IIB. Also, sub-cluster IIA is divided into two sub-clusters, namely sub-cluster IIA (i) and sub-cluster IIA (ii). The sub-cluster IIA (i) corresponds to E. globulus in sub-cluster IIA (ia), together with E. pellita, E. globulus, and Eucalyptus sp. in sub-cluster IIA (ib), Furthermore, sub-cluster IIA (ii) consisted of 5 accessions of E. deglupta. Sub-cluster IIB is divided into two sub-clusters, namely sub-cluster IIB (i) and sub-cluster IIB (ii). Similarly, sub-cluster IIB (i) corresponds to E. urophylla, while sub-cluster IIB (ii) corresponds to Eucalyptus sp.

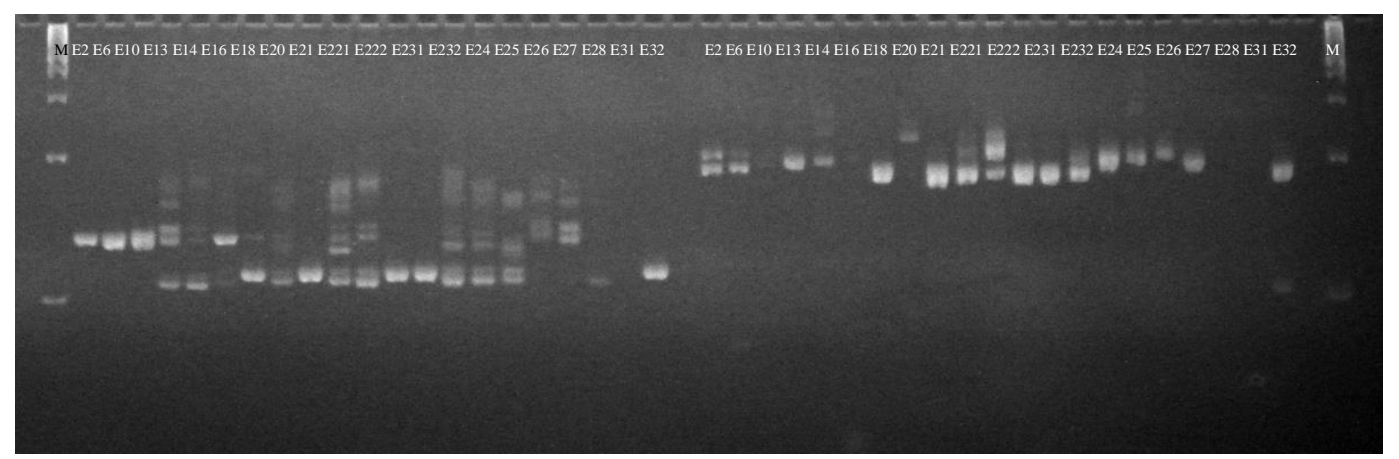

Figure 2. Electropherogram of eucalypts genotyping analysis with EMCRC3 (left) and EMCRC4 (right) markers on $8 \%$ gel electrophoresis. Lane 1: 100 bp Ladder, Lane 2-21: eucalypts accessions. M: marker 
Table 2. Primer sequences used in this study

\begin{tabular}{|c|c|c|c|c|c|}
\hline Primer & SSR motif & Primer sequences & Size (bp) & Source & Reference \\
\hline EMBRA1 & (AG)33 & $\begin{array}{l}\text { 5-GATAGAACTTTCCTATTTGATCG-3 } \\
\text { 5-GTAGGATTTGATGTCTGCAA-3 }\end{array}$ & 127 & E. grandis $\times$ E. urophylla & Brondani et al. (1998) \\
\hline EMBRA2* & (AG) 15 & $\begin{array}{l}\text { 5-CGTGACACCAGGACATTAC-3 } \\
\text { 5-ACAAATGCAAATTCAAATGA-3 }\end{array}$ & 121 & E. grandis $\times$ E. urophylla & Brondani et al. (1998) \\
\hline EMBRA3* & (AG) 19 & $\begin{array}{l}\text { 5-GATCGGATTGGA GGAGAC-3 } \\
\text { 5-AATTCAATTCATCCAAAGC-3 }\end{array}$ & 123 & E. grandis $\times$ E. urophylla & Brondani et al. (1998) \\
\hline EMBRA7 & (AG) 15 & $\begin{array}{l}\text { 5-CACACCGTGTCAGTTAGC-3 } \\
\text { 5-AATAAG GAGGATTCCATGG-3 }\end{array}$ & 115 & E. grandis $\times$ E. urophylla & Brondani et al. (1998) \\
\hline EMBRA8* & $(\mathrm{AG}) 21$ & $\begin{array}{l}\text { 5-CACAACTAAAAATCAAAACCC-3 } \\
\text { 5-AAAGAGCAGATTATTACAGAAGC-3 }\end{array}$ & 127 & E. grandis $\times$ E. urophylla & Brondani et al. (1998) \\
\hline EMBRA13* & (AG)27 & $\begin{array}{l}\text { 5-ATTTCCCTAGGTTTGACATG-3 } \\
\text { 5-TCCAACATCTTACTCAACCA-3 }\end{array}$ & 130 & E. grandis $\times$ E. urophylla & Brondani et al. (1998) \\
\hline EMBRA17* & (AG) 18 & $\begin{array}{l}\text { 5-AGGATACTCGTG AGAGAAGC-3 } \\
\text { 5-GTAGATCTGTTCTGCATG TTG-3 }\end{array}$ & 184 & E. grandis $\times$ E. urophylla & Brondani et al. (1998) \\
\hline EMBRA19 & (AG)23 & $\begin{array}{l}\text { 5-GACGGTTGATTTCCTGAT T-3 } \\
\text { 5-GTGGTGCTCCTCTCCTCT-3 }\end{array}$ & 124 & E. grandis $\times$ E. urophylla & Brondani et al. (1998) \\
\hline EMCRC3* & (CA) 10 & $\begin{array}{l}\text { 5-AGATGGGGTTTCTCATGGTTT-3 } \\
\text { 5-ACCGTACTATGCAGCTGGAAC-3 }\end{array}$ & $109-145$ & E. globulus & Steane, et al. (2001) \\
\hline EMCRC4* & (AC) 17 & $\begin{array}{l}\text { 5-GTAATCTTTCATTCTCCGACC-3 } \\
\text { 5-CTCGAGGACATGTTGAGTG-3 }\end{array}$ & $178-268$ & E. globulus & Steane, et al. (2001) \\
\hline EMCRC6* & $(\mathrm{CT}) 11(\mathrm{CA}) 23$ & $\begin{array}{l}\text { 5-CTTCAAGGTTCACAGATGG-3 } \\
\text { 5-TCTTCATAAGTCCCCTAATCA-3 }\end{array}$ & $151-193$ & E. globulus & Steane, et al. (2001) \\
\hline EMCRC11* & (TC) $10(\mathrm{AC}) 10$ & $\begin{array}{l}\text { 5-AACTGACTGTGGATTTAAGC-3 } \\
\text { 5-GTGAGTCATTATTTGGCAACC-3 }\end{array}$ & 22 & E. globulus & al. (2001) \\
\hline EMCRC12* & $(\mathrm{CT}) 8(\mathrm{CA}) 14$ & $\begin{array}{l}\text { 5-CTCCGACCTCCTCCACT-3 } \\
\text { 5-AATCGTCTTCATCGAATCAAG-3 }\end{array}$ & $70-128$ & E. globulus & Steane, et al. (2001) \\
\hline EMCRC41* & $(\mathrm{GA}) 24$ & $\begin{array}{l}\text { 5-GACGGTAGCATTCTGTTCTTTGGCA-3 } \\
\text { 5-TGGGTCGACTTTCAAGTCGCGT-3 }\end{array}$ & $114-150$ & C. citriodora & Shepherd et al. (2006) \\
\hline EMCRC49 & $(\mathrm{GA}) 11(\mathrm{~A}) 7(\mathrm{GA})$ & $\begin{array}{l}\text { 25-ACCAAGAAACGGGGAAAGAG-3 } \\
\text { 5-GTTTTGGAGAGAGGGGCAAG-3 }\end{array}$ & $251-286$ & C. citriodora & Shepherd et al. (2006) \\
\hline EMCRC51* & $(\mathrm{GA}) 15$ & $\begin{array}{l}\text { 5-CTCGACCACCCGAGAGAA-3 } \\
\text { 5-CACAGAATTCACTCCCTCCTAAA-3 }\end{array}$ & $250-277$ & C. citriodora & Shepherd et al. (2006) \\
\hline EMCRC55* & $(\mathrm{GA}) 21$ & $\begin{array}{l}\text { 5-TGTAGATAAGGCGTGGAGAGG-3 } \\
\text { 5-GCATACAATTATCCGCCAGAG-3 }\end{array}$ & $270-297$ & C. citriodora & Shepherd et al. (2006) \\
\hline EMCRC93* & (GA) 16 & $\begin{array}{l}\text { 5-GCAACTCCAACGACAACAAC-3 } \\
\text { 5-GGTCAATCTCCTCCACCAGTAA-3 }\end{array}$ & $131-166$ & C. citriodora & Shepherd et al. (2006) \\
\hline eSSR-GR046 & (GGACCG)4 & $\begin{array}{l}\text { 5-AAACAACCCGAACGAAAGAA-3 } \\
\text { 5-GGAGGTCCTACTACACCCACAA-3 }\end{array}$ & 170 & E. pellita & Liu et al. (2018a) \\
\hline eSSR-GR124 & $(\mathrm{GTT}) 8$ & $\begin{array}{l}\text { 5-ATTGATTCACGGACACGG-3 } \\
\text { 5-GAACGCAATCCCACCTAA-3 }\end{array}$ & 279 & E. pellita & Liu et al. (2018a) \\
\hline eSSR-GR127 & $(\mathrm{GCAGCG}) 3$ & $\begin{array}{l}\text { 5-CGCTGTCCATCGTGTATTTG-3 } \\
\text { 5-TGACGCTGTCGGTGAAACT-3 }\end{array}$ & 371 & E. pellita & Liu et al. (2018a) \\
\hline gSSR-CA013 & (CT) 10 & $\begin{array}{l}\text { 5-AGATGGGACGGACGAGGAT-3 } \\
\text { 5-GGTGGTGCTGGGAAGAAT-3 }\end{array}$ & 121 & E. pellita & Liu et al. (2018a) \\
\hline gSSR-GU023 & (AGAAAA)3 & $\begin{array}{l}\text { 5-GAGCCTGTTACAAATGGA-3 } \\
\text { 5-TCACAGCAGTCGGTCTTT -3 }\end{array}$ & 316 & E. pellita & Liu et al. (2018a) \\
\hline
\end{tabular}

Note: *Fourteen selected primers were used for further analysis

In sub-cluster IIA (ib), the two closely related accessions of E. pellita are E20 and E32 from the same regions (Karanganyar, Central Java), with a genetic similarity value of $100 \%$. The two closely related accessions of $E$. deglupta namely in sub-cluster IIA (ii) include E23-1 and E23-2 from the same regions (Bogor, West Java), with a genetic similarity value of $90 \%$. In addition, there are also two distant related accessions namely E16 (C. citriodora) from Karanganyar, Central Java, while E22-2 (E. urophylla) is from Garut, West Java with a genetic similarity value of $43 \%$ (Table 5).

The Principal Coordinate Analysis (PCoA) in two spatial dimensions (XY coordinates) showed the total value of variance at each coordinate. Based on this result, the
PCoA has identified two groups that clearly distinguish and each genotype is grouped based on its genus, namely Corymbia (right) and Eucalyptus (left) (Figure 4). The Corymbia in the blue rhombus type is grouped into $C$. citriodora, while within the Eucalyptus group, the individual trees with a triangular shape are grouped into $E$. deglupta was separated from other Eucalyptus species at the upper left coordinate. Although the other 4 Eucalyptus species (E. urophylla, E. pellita, E. globulus, and Eucalyptus sp) were not distinguished, there is a slight difference between each species such as in the shape of crosses grouped into Eucalyptus sp., in blue star grouped into E. globulus, in orange box grouped into the $E$. urophylla, in green circle grouped into E. pellita. 


\section{Population structure of eucalypts}

There were 14 SSR markers used to determine the population structure of eucalypts species. The results showed that the peak of delta-K continued to decline after $k$ $=6$, which suggested that the existence of 6 populations (Figure 5). At $k=6$, eucalypts species were distinguished into 6 populations and most of the populations were homogeneous with little admixture apart. This showed that Group 1 corresponded to C. citriodora (20\%), Group 2 corresponded to E. urophylla (15\%), Group 3 corresponded to E. deglupta (25\%), Group 4 corresponded to E. pellita (10\%), Group 5 corresponded to Eucalyptus sp. (10\%), and Group 6 corresponded to E. globulus (20\%). In addition, the Eucalyptus sp. consisted of E26 which corresponded to Group 2 or belongs to E. urophylla, E24 corresponded to Group 6 or belongs to E. globulus, while E25 and E27 corresponded to Group 5 or belongs to Eucalyptus sp.

\section{Discussion}

This study determined the genetic diversity and population structure of Corymbia and Eucalyptus species using 14 SSR markers. Although the success rate of genomic SSR marker in eucalypt from is transferable, it is relatively low $(>50 \%)$ compared to cross-species transferability on other eucalypt species (Subashini et al. 2014; Kotrappa et al. 2017; Liu et al. 2018b). Many isolated SSR markers from E. grandis and E. urophylla (EMBRA code) were cross-amplified in different Eucalyptus species such as E. globulus, E. pilularis, E. nitens, E. urophylla, E. pyrocarpa, E. camaldulensis, and E. tereticornis (Bundock et al. 2000; Steane et al. 2001; Glaubitz et al. 2001; Agrama et al. 2002; Ottewell et al. 2005; Arumugasundaram et al. 2011; Subashini et al. 2014). Similarly, e-SSR markers were successfully crossamplified in several species such as E. dunnii, E. saligna, E. camaldulensis, E. viminalis, E. urophylla, and E. tereticornis (Faria et al. 2010; Hudson et al. 2012; Acuna et al. 2012; He et al. 2012; He et al. 2015; Breed et al. 2012; Bradbury et al. 2013).
One of the determining factors for successful amplification of SSR markers is the genetic relationship of each taxonomic or phylogenetic distance (Chandra et al. 2011). The success of SSR amplification occurred with subgenus, genus, subfamily, even family (McCulloch and Stevens 2011). In this study, the SSR markers used are transferable in different genera (Corymbia and Eucalyptus) and the Eucalyptus species used belong to the same subgenus, namely Symphyomyrtus (Brondani et al. 1998). Moreover, the polymorphism rate of SSR amplification in E. urophylla and Eucalyptus sp. was higher than $C$. citriodora, E. globulus, and E. deglupta, while E. pellita was weakly transferred. This is in line with a study by Nurtjahjaningsih et al. (2013) which stated that the amplification of $E$. urohpylla was higher than $E$. deglupta.

The SSR markers were successfully amplified when carried out in the same genus with the source of the marker. However, when it was conducted against other species, the success rate decreased even within the same taxa (Ujino et al. 1998). Although the source of SSR marker was from $E$. grandis $X$ E. urophylla (EMBRA) and E. globulus (EMCRC), however, all the SSR markers did not amplify polymorphic allele on E. urophylla and E. globulus accession. This was similar to a study by Nurtjahjaningsih et al. (2013) which showed that the SSR amplification does not always work even on the same species. This indicated that in addition to proximity taxonomically, the size and complexity of DNA composition are also important in the polymorphism of the SSR screening. The size of the genetic disorders caused by the evolutionary process also affected successful SSR amplification, even the deviation varies between loci. In addition, the polymorphic allele is affected by perfect or the SSR repeat structure. Since the mutation rate interrupts the base arrangement in SSR sequences, therefore, the structure of the replication is not perfect. This affects the degree of polymorphism of allele amplification or causes inhibition. Moreover, the decreasing distance also influences the phylogenetic allelic polymorphism of the species (Jan et al. 2012).

Table 3. The number of amplified markers of eucalypt in this study

\begin{tabular}{|c|c|c|c|c|c|c|}
\hline Primer & C. citriodora & E. urophylla & E. deglupta & Eucalyptus sp. & E. globulus & E. pellita \\
\hline EMCRC11 & $\mathrm{M}$ & $P$ & $P$ & $P$ & $\mathrm{M}$ & $\mathrm{M}$ \\
\hline EMCRC41 & $\mathrm{P}$ & $\mathrm{M}$ & $\mathrm{M}$ & M & M & M \\
\hline EMCRC51 & $\mathrm{P}$ & $\mathrm{P}$ & $\mathrm{M}$ & $\mathrm{P}$ & $\mathrm{P}$ & $\mathrm{M}$ \\
\hline EMCRC55 & $\mathrm{P}$ & M & $\mathrm{P}$ & $\mathrm{P}$ & $\mathrm{P}$ & $\mathrm{M}$ \\
\hline EMCRC93 & $\mathrm{P}$ & $\mathrm{P}$ & $\mathrm{M}$ & $\mathrm{P}$ & $\mathrm{P}$ & $\mathrm{M}$ \\
\hline EMBRA2 & $\mathrm{P}$ & $\mathrm{P}$ & $\mathrm{M}$ & $\mathrm{P}$ & $\mathrm{P}$ & $\mathrm{M}$ \\
\hline EMBRA3 & M & $\mathrm{P}$ & $\mathrm{P}$ & $\mathrm{P}$ & M & $\mathrm{P}$ \\
\hline EMBRA8 & $\mathrm{P}$ & M & $\mathrm{P}$ & $\mathrm{P}$ & $\mathrm{P}$ & M \\
\hline EMBRA17 & M & $\mathrm{P}$ & $\mathrm{P}$ & $\mathrm{P}$ & M & $\mathrm{M}$ \\
\hline EMCRC3 & $\mathrm{M}$ & $\mathrm{P}$ & $\mathrm{M}$ & $\mathrm{P}$ & $\mathrm{P}$ & $\mathrm{M}$ \\
\hline EMCRC4 & $\mathrm{P}$ & M & $\mathrm{M}$ & $\mathrm{P}$ & $\mathrm{P}$ & $\mathrm{M}$ \\
\hline EMBRA 13 & $\mathrm{P}$ & $\mathrm{P}$ & $\mathrm{P}$ & $\mathrm{P}$ & $\mathrm{P}$ & $\mathrm{M}$ \\
\hline EMCRC6 & $\mathrm{M}$ & $\mathrm{P}$ & $\mathrm{P}$ & M & $\mathrm{M}$ & $\mathrm{M}$ \\
\hline EMCRC12 & $\mathrm{M}$ & $\mathrm{P}$ & $\mathrm{M}$ & $\mathrm{P}$ & $\mathrm{M}$ & $\mathrm{M}$ \\
\hline Polymorphic (P) & 8 & 10 & 7 & 12 & 8 & 1 \\
\hline Monomorphic (M) & 6 & 4 & 7 & 2 & 6 & 13 \\
\hline Polymorphism rate (\%) & 57.1 & 71.4 & 50.0 & 85.7 & 57.1 & 7.1 \\
\hline
\end{tabular}


Table 4. Genetic diversity of eucalypts generated by 14 SSR markers

\begin{tabular}{|c|c|c|c|c|c|c|c|c|c|c|c|c|c|c|c|c|}
\hline \multirow{2}{*}{ Population } & & \multicolumn{14}{|c|}{ SSR marker } & \multirow[t]{2}{*}{ Mean } \\
\hline & & $\overline{\text { EMCRC11 }}$ & EMCRC41 & EMCRC51 & EMCRC55 & EMCRC93 & EMBRA2 & EMBRA3 & EMBRA8 & EMBRA17 & EMCRC3 & EMCRC4 & EMBRA13 & EMCRC6 & EMCRC12 & \\
\hline \multirow{6}{*}{ C. citriodora } & $\mathrm{N}$ & 4 & 4 & 4 & 4 & 4 & 4 & 4 & 4 & 4 & 4 & 4 & 4 & 4 & 4 & 4.0 \\
\hline & $\mathrm{N} a$ & 1 & 2 & 2 & 2 & 2 & 4 & 1 & 2 & 1 & 1 & 2 & 2 & 1 & 1 & 1.71 \\
\hline & $\mathrm{Ho}$ & 0.00 & 0.25 & 0.00 & 0.00 & 0.00 & 0.75 & 0.00 & 0.00 & 0.00 & 0.00 & 0.00 & 1.00 & 0.00 & 0.00 & 0.14 \\
\hline & $\mathrm{He}$ & 0.00 & 0.22 & 0.38 & 0.38 & 0.38 & 0.66 & 0.00 & 0.50 & 0.00 & 0.00 & 0.38 & 0.50 & 0.00 & 0.00 & 0.24 \\
\hline & Fis & $\sim$ & $-0.14^{\mathrm{ns}}$ & $1.00^{*}$ & $1.00 *$ & $1.00 *$ & $-0.14^{\mathrm{ns}}$ & $\sim$ & $1.00^{*}$ & $\sim$ & $\sim$ & $1.00^{*}$ & $-1.00 *$ & $\sim$ & $\sim$ & 0.46 \\
\hline & $\mathrm{N}$ & 2 & 2 & 2 & 2 & 2 & 2 & 2 & 2 & 2 & 2 & 2 & 2 & 2 & 2 & 2 \\
\hline \multirow[t]{4}{*}{ E. urophylla } & $\mathrm{N} a$ & 2 & 1 & 2 & 1 & 2 & 2 & 3 & 1 & 2 & 2 & 1 & 3 & 3 & 2 & 1.93 \\
\hline & $\mathrm{Ho}$ & 0.50 & 0.00 & 0.00 & 0.00 & 0.50 & 1.00 & 0.50 & 0.00 & 0.00 & 0.50 & 0.00 & 1.00 & 0.50 & 0.50 & 0.36 \\
\hline & $\mathrm{He}$ & 0.38 & 0.00 & 0.50 & 0.00 & 0.38 & 0.50 & 0.63 & 0.00 & 0.50 & 0.38 & 0.00 & 0.63 & 0.63 & 0.38 & 0.35 \\
\hline & Fis & $-0.33^{\text {ns }}$ & $\sim$ & $1.00^{\mathrm{ns}}$ & $\sim$ & $-0.33^{\text {ns }}$ & $-1.00^{\mathrm{ns}}$ & $0.20^{\mathrm{ns}}$ & $\sim$ & $1.00^{\mathrm{ns}}$ & $-0.33^{\mathrm{ns}}$ & $\sim$ & $-0.60^{\text {ns }}$ & $0.20^{\text {ns }}$ & $-0.33^{\text {ns }}$ & -0.05 \\
\hline \multirow[t]{5}{*}{ E. deglupta } & $\mathrm{N}$ & 5 & 5 & 5 & 5 & 5 & 5 & 5 & 5 & 5 & 5 & 5 & 5 & 5 & 5 & 5 \\
\hline & $\mathrm{N} a$ & 2 & 1 & 1 & 2 & 1 & 1 & 3 & 2 & 2 & 1 & 1 & 3 & 2 & 1 & 1.64 \\
\hline & $\mathrm{Ho}$ & 0.00 & 0.00 & 0.00 & 0.20 & 0.00 & 0.00 & 0.40 & 0.00 & 0.00 & 0.00 & 0.00 & 0.40 & 0.60 & 0.00 & 0.11 \\
\hline & $\mathrm{He}$ & 0.32 & 0.00 & 0.00 & 0.50 & 0.00 & 0.00 & 0.56 & 0.32 & 0.48 & 0.00 & 0.00 & 0.64 & 0.42 & 0.00 & 0.23 \\
\hline & Fis & $1.00^{*}$ & $\sim$ & $\sim$ & $0.60^{\text {ns }}$ & $\sim$ & $\sim$ & $0.29^{\text {ns }}$ & $1.00^{*}$ & $1.00^{*}$ & $\sim$ & $\sim$ & $0.38^{\text {ns }}$ & $-0.43^{\text {ns }}$ & $\sim$ & 0.55 \\
\hline Eucalyptus & $\mathrm{N}$ & 4 & 3 & 4 & 4 & 4 & 4 & 4 & 4 & 4 & 4 & 4 & 4 & 4 & 4 & 3.93 \\
\hline \multirow[t]{4}{*}{ sp. } & $\mathrm{N} a$ & 3 & 1 & 2 & 3 & 3 & 2 & 2 & 2 & 2 & 3 & 2 & 3 & 1 & 3 & 2.29 \\
\hline & $\mathrm{Ho}$ & 0.00 & 0.00 & 0.00 & 0.50 & 0.25 & 0.25 & 0.00 & 0.00 & 0.00 & 0.75 & 0.00 & 0.75 & 0.00 & 0.75 & 0.23 \\
\hline & $\mathrm{He}$ & 0.63 & 0.00 & 0.38 & 0.59 & 0.53 & 0.47 & 0.38 & 0.38 & 0.38 & 0.66 & 0.38 & 0.59 & 0.00 & 0.53 & 0.42 \\
\hline & Fis & $1.00^{*}$ & $\sim$ & $1.00 *$ & $0.16^{\mathrm{ns}}$ & $0.53^{\mathrm{ns}}$ & $0.47^{\mathrm{ns}}$ & $1.00^{*}$ & $1.00^{*}$ & $1.00^{*}$ & $-0.14 *$ & $1.00^{*}$ & $-0.26^{\mathrm{ns}}$ & $\sim$ & $-0.41^{\mathrm{ns}}$ & 0.53 \\
\hline \multirow[t]{5}{*}{ E. globulus } & $\mathrm{N}$ & 3 & 2 & 3 & 3 & 3 & 3 & 3 & 3 & 3 & 3 & 3 & 3 & 3 & 3 & 2.93 \\
\hline & $\mathrm{N} a$ & 1 & 1 & 2 & 2 & 2 & 2 & 1 & 2 & 1 & 3 & 2 & 2 & 1 & 1 & 1.64 \\
\hline & $\mathrm{Ho}$ & 0.00 & 0.00 & 0.00 & 1.00 & 0.00 & 0.00 & 0.00 & 0.00 & 0.00 & 0.33 & 0.00 & 0.67 & 0.00 & 0.00 & 0.14 \\
\hline & $\mathrm{He}$ & 0.00 & 0.00 & 0.44 & 0.50 & 0.44 & 0.44 & 0.00 & 0.44 & 0.00 & 0.61 & 0.44 & 0.44 & 0.00 & 0.00 & 0.27 \\
\hline & Fis & $\sim$ & $\sim$ & $1.00^{\mathrm{ns}}$ & $-1.00^{\mathrm{ns}}$ & $1.00^{\mathrm{ns}}$ & $1.00^{\mathrm{ns}}$ & $\sim$ & $1.00^{\mathrm{ns}}$ & $\sim$ & $0.45^{\mathrm{ns}}$ & $1.00^{\mathrm{ns}}$ & $-0.50^{\text {ns }}$ & $\sim$ & $\sim$ & 0.49 \\
\hline \multirow[t]{5}{*}{ E. pellita } & $\mathrm{N}$ & 1 & 2 & 2 & 1 & 2 & 1 & 2 & 2 & 2 & 2 & 2 & 2 & 1 & 1 & 1.64 \\
\hline & $\mathrm{N} a$ & 1 & 1 & 1 & 1 & 1 & 1 & 2 & 1 & 1 & 1 & 1 & 1 & 1 & 1 & 1.07 \\
\hline & $\mathrm{Ho}$ & 0.0 & 0.0 & 0.0 & 0.0 & 0.0 & 0.0 & 1.0 & 0.0 & 0.0 & 0.0 & 0.0 & 0.0 & 0.0 & 0.0 & 0.07 \\
\hline & $\mathrm{He}$ & 0.0 & 0.0 & 0.0 & 0.0 & 0.0 & 0.0 & 0.5 & 0.0 & 0.0 & 0.0 & 0.0 & 0.0 & 0.0 & 0.0 & 0.04 \\
\hline & Fis & $\sim$ & $\sim$ & $\sim$ & $\sim$ & $\sim$ & $\sim$ & $-1.0^{\mathrm{ns}}$ & $\sim$ & $\sim$ & $\sim$ & $\sim$ & $\sim$ & $\sim$ & $\sim$ & -1.00 \\
\hline PIC & & 0.68 & 0.35 & 0.54 & 0.57 & 0.58 & 0.69 & 0.55 & 0.65 & 0.51 & 0.48 & 0.43 & 0.63 & 0.55 & 0.52 & 0.55 \\
\hline
\end{tabular}

Note: N: Number of samples. Na: Number of the detected allele. Ho: Observed heterozygosity. He: Expected heterozygosity. Fis: Inbreeding coefficient. PIC: Polymorphic Information Content. ns: not significant. $* P<0.05 ; \sim$ : allele monomorphic 
Table 5. The genetic similarity matrix of eucalypts in this study was generated by 14 SSR markers

\begin{tabular}{|c|c|c|c|c|c|c|c|c|c|c|c|c|c|c|c|c|c|c|c|c|}
\hline Accession & E10 & E13 & E14 & E16 & E18 & E2 & E20 & E21 & E22_1 & E22_2 & E23_1 & E23_2 & E24 & E25 & E26 & E27 & E28 & E31 & E32 & E6 \\
\hline E10 & 1.00 & & & & & & & & & & & & & & & & & & & \\
\hline E13 & 0.55 & 1.00 & & & & & & & & & & & & & & & & & & \\
\hline E14 & 0.53 & 0.86 & 1.00 & & & & & & & & & & & & & & & & & \\
\hline E16 & 0.73 & 0.61 & 0.59 & 1.00 & & & & & & & & & & & & & & & & \\
\hline E18 & 0.65 & 0.65 & 0.67 & 0.67 & 1.00 & & & & & & & & & & & & & & & \\
\hline E2 & 0.84 & 0.55 & 0.61 & 0.73 & 0.69 & 1.00 & & & & & & & & & & & & & & \\
\hline E20 & 0.63 & 0.67 & 0.73 & 0.65 & 0.65 & 0.63 & 1.00 & & & & & & & & & & & & & \\
\hline E21 & 0.57 & 0.65 & 0.71 & 0.67 & 0.80 & 0.65 & 0.73 & 1.00 & & & & & & & & & & & & \\
\hline E22_1 & 0.57 & 0.57 & 0.55 & 0.59 & 0.55 & 0.61 & 0.61 & 0.59 & 1.00 & & & & & & & & & & & \\
\hline E22_2 & 0.53 & 0.53 & 0.67 & 0.43 & 0.59 & 0.53 & 0.61 & 0.55 & 0.67 & 1.00 & & & & & & & & & & \\
\hline E23_1 & 0.47 & 0.63 & 0.69 & 0.53 & 0.69 & 0.51 & 0.71 & 0.78 & 0.57 & 0.69 & 1.00 & & & & & & & & & \\
\hline $\mathrm{E} 232$ & 0.53 & 0.61 & 0.67 & 0.59 & 0.76 & 0.57 & 0.65 & 0.84 & 0.63 & 0.67 & 0.90 & 1.00 & & & & & & & & \\
\hline E24 & 0.61 & 0.65 & 0.67 & 0.63 & 0.71 & 0.53 & 0.57 & 0.67 & 0.59 & 0.59 & 0.61 & 0.67 & 1.00 & & & & & & & \\
\hline E25 & 0.61 & 0.49 & 0.51 & 0.51 & 0.63 & 0.57 & 0.69 & 0.55 & 0.67 & 0.67 & 0.61 & 0.63 & 0.67 & 1.00 & & & & & & \\
\hline E26 & 0.65 & 0.53 & 0.51 & 0.59 & 0.59 & 0.53 & 0.69 & 0.47 & 0.59 & 0.63 & 0.57 & 0.55 & 0.59 & 0.67 & 1.00 & & & & & \\
\hline E27 & 0.69 & 0.57 & 0.63 & 0.76 & 0.67 & 0.65 & 0.78 & 0.67 & 0.63 & 0.59 & 0.57 & 0.59 & 0.63 & 0.67 & 0.71 & 1.00 & & & & \\
\hline E28 & 0.59 & 0.71 & 0.69 & 0.57 & 0.57 & 0.55 & 0.80 & 0.69 & 0.57 & 0.61 & 0.67 & 0.65 & 0.53 & 0.57 & 0.57 & 0.73 & 1.00 & & & \\
\hline E31 & 0.53 & 0.69 & 0.71 & 0.63 & 0.71 & 0.61 & 0.73 & 0.71 & 0.55 & 0.63 & 0.82 & 0.76 & 0.63 & 0.67 & 0.59 & 0.67 & 0.69 & 1.00 & & \\
\hline E32 & 0.63 & 0.67 & 0.73 & 0.65 & 0.65 & 0.63 & 1.00 & 0.73 & 0.61 & 0.61 & 0.71 & 0.65 & 0.57 & 0.69 & 0.69 & 0.78 & 0.80 & 0.73 & 1.00 & \\
\hline E6 & 0.82 & 0.53 & 0.55 & 0.76 & 0.63 & 0.82 & 0.57 & 0.59 & 0.51 & 0.47 & 0.57 & 0.63 & 0.55 & 0.51 & 0.59 & 0.63 & 0.53 & 0.63 & 0.57 & 1.00 \\
\hline
\end{tabular}




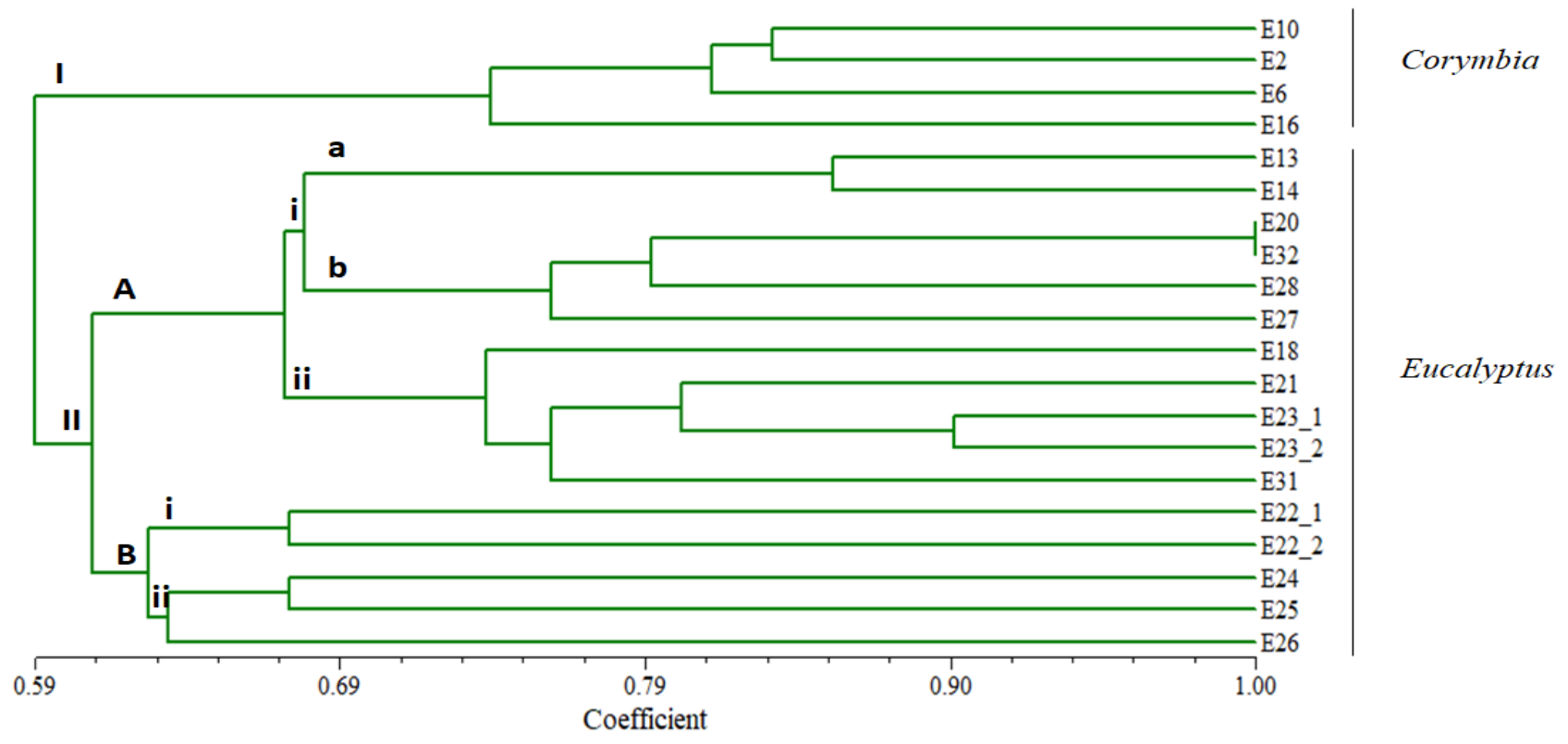

Figure 3. UPGMA dendrogram of Corymbia and Eucalyptus showing the genetic relationships among the 20 accessions generated by 14 SSR markers

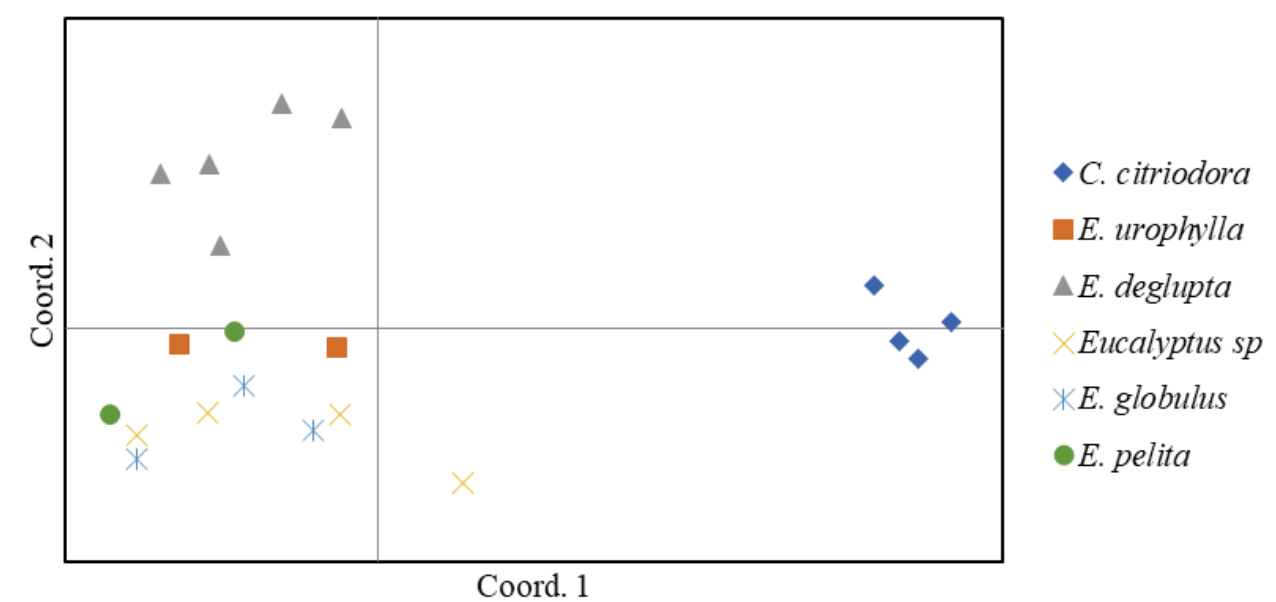

Figure 4. PCoA of inter-individual coordinates of Corymbia and Eucalyptus

In this study, the relatively small plant material coverage gave smaller allele numbers (average of 3 alleles per marker) and a low level of genetic diversity (mean $\mathrm{He}$ = 0.26). This showed that Eucalyptus sp. and E. urophylla were the highest gene diversity, followed by E. globulus, C. citriodora, E. deglupta, and E. pellita compared to previous studies (Nurtjahjaningsih et al. 2013; Kotrappa et al. 2017; and Liu et al. 2018b). The genetic diversity of $E$. globulus, C. citriodora, E. deglupta was not significantly high compared to Eucalyptus sp. and E. urophylla with the continuous (connected) distribution. Also, fragmented distribution hindered the flow of genes or migration rate per generation, which affected the structure of genes and caused the low value of genetic diversity (Hu et al. 2010;
Karan et al. 2012). However, the low level of gene diversity value in $C$. citriodora, E. deglupta, and Eucalyptus sp. did not show a heterozygosity deficit because of the inbreeding coefficient value (Fis) were 0.46 , 0.55 , and 0.53 . respectively. This indicated that each of the three species used in this study came from a random mating system. Although the value of gene diversity in E. deglupta was lower than Eucalyptus sp. and C. citriodora, the inbreeding coefficient value of E. deglupta was higher. In addition, the low value of gene diversity in E. globulus did not significantly deviate from the HWE. However, a previous study by Costa et al. (2017) stated that the high value of gene diversity in E. globulus did not significantly deviate from the HWE. Since the mean observed 
heterozygosity (Ho) was 0.19 derived from C. citriodora, E. urophylla, E. deglupta, Eucalyptus sp., and E. globulus, it indicated that most markers used detected more than one allele per accession, as expected for accessions directly derived from landraces. The mean $\mathrm{Ho}$ in E. pellita was 0.07 , which indicated that the accessions are highly inbred since the accessions of a largely self-pollinated species are maintained in the collections. Therefore, further studies are required by increasing the number of populations and samples with more diverse populations. In addition, the use of genetically related species also causes a high inbreeding coefficient.

The PIC value provided information about the polymorphism of a marker, meanwhile, a study by Botstein et al. (1980) stated that a PIC value $>0.5$ gave high information. Also, PIC values between $0.25-0.5$ gave moderate information, while a PIC value of $<0.25$ gave little information. In this study, the PIC value $(\mathrm{PIC}=0.55)$ was higher than Liu et al. (2017) which observed the PIC value of 0.49 from six species of Eucalyptus. In contrast, higher mean PIC value (>0.75) from 4 Corymbia and 36 Eucalyptus species (Liu et al. 2018b), C. citriodora (Liu et al. 2016), and 20 eucalypt genotypes (He et al. 2015). Therefore, the higher the PIC value of the SSR marker, the greater the potential of identifying genetic relationships, which are influenced by the characteristics of the marker and species differences. Among 14 SSR markers, 4 makers with high PIC values $(>0.6)$, which indicated their ability to distinguish between and within the individuals in a population. However, the e-SSR markers used gave low levels of polymorphism in Corymbia and 5 Eucalyptus species compared to the genomic SSR marker. In the eSSR markers, the relatively low level of polymorphism is due to the location of these markers in more conserved and expressed sequences compared to the genomic sequences which are spread throughout (Parthiban et al. 2018).

In this study, the cluster analysis illustrated by the UPGMA dendrogram showed the genetic relationship of eucalypt into two distinct groups, namely Corymbia species, C. citriodora which belongs to subgenus Blakella, and Eucalyptus species from the subgenus Symphyomyrtus as the largest (Júnior and Garcia 2021). This is in line with the Eucalyptus taxonomic classifications of Nicolle (2019) and chloroplast genome analysis (Bayly et al. 2013). Meanwhile, the Australian Plants Society (2016) stated the differences between Corymbia and Eucalyptus based on the type of bark, juvenile, and mature leaves, as well as fruit/capsules and buds. In Corymbia, the diverse and widespread bloodwoods, spotted, lemon-scented, and ghost gums as well as the fruit has many typical bloodwood shapes with no teeth and are not ribbed. Meanwhile, Eucalyptus is very diverse and widespread gum, while peppermint, ironbark, stringybark, mahogany, ash, blackbutt, box, tallowwood, and the fruit is a woody capsule, size variable, not ribbed or toothed, and variable shape. In this study, E. globulus (section Maidenaria), E. pellita (section Latoangulatae), and E. deglupta (section Equatoria) were clustered together in group IIA, while Eucalyptus sp. was in the same cluster with E. urophylla (section Latoangulatae) in group IIB. Moreover, the clustering of group IIA supported the hypothesis of Bayly et al. (2013) that analyzed chloroplast genomes of 39 eucalypt species of Eucalyptus, Corymbia, and Angophora discovered that E. globulus (subgenus Eucalyptus) together with E. deglupta was placed with each other in close genetic proximity (at node 27). The clustering in group IIB, E. urophylla were clustered separately with E. pellita in group IIA. This is notably different from a study by Liu et al. (2018b) which clustered E. urophylla and E. pellita in the same cluster.

The PCoA analysis showed that one species of Corymbia and five species of Eucalyptus were distinguished by each genus. The genetic relationship among the species of Eucalyptus and E. deglupta was separated from the other 4 Eucalyptus species (E. urophylla, E. globulus, E. pellita, and Eucalyptus sp.), which showed that the genetic purity of each species is still maintained. Moreover, the PCoA analysis usually indicated the geographic location with the genetic analysis of a species. In this study, E. deglupta originated from Bogor, West Java which is closer to E. urophylla from Garut, West Java, however, it was separated in the different ordinate side with E. urophylla. The E. urophyllla was clustered together with E. pellita, E. globulus, and Eucalyptus sp. from Karanganyar, Central Java. This is not in line with a study by Nurtjahjaningsih et al. (2013) which stated that the PCoA gave the E. urophylla and E. deglupta from Yogyakarta, clustered together on the same ordinate side (right side of form the $\mathrm{Y}$ ordinate), while E. pellita on the other side of the ordinate (to the left of Y-ordinate).

Based on the peak of delta-K, the population structure was divided into six, where Group 1 corresponded to $C$. citriodora), Group 2 corresponded to E. urophylla, Group 3 corresponded to E. deglupta, Group 4 corresponded to $E$. pellita, Group 5 corresponded to Eucalyptus sp., and Group 6 corresponded to E. globulus. Based on the geographical location, the first three groups (C. citriodora, E. urophylla, and E. deglupta) were cultivated from West Java, and the second three groups (E. pellita, Eucalyptus sp., and E. globulus) from Central Java. In this study, it was assumed that the geographic distribution of West and Central Java promotes the adaptation to the same environment (tropical environment) caused similarities in gene structure. Meanwhile, the genetic variation within a species generally has a geographic basis, since the processes of adaptation, gene flow, and genetic drift which act differently in heterogeneous landscapes and are strongly influenced by the demographics and spatial distribution of populations (Eckert et al. 2008; Junior and Garcia 2021). 
A

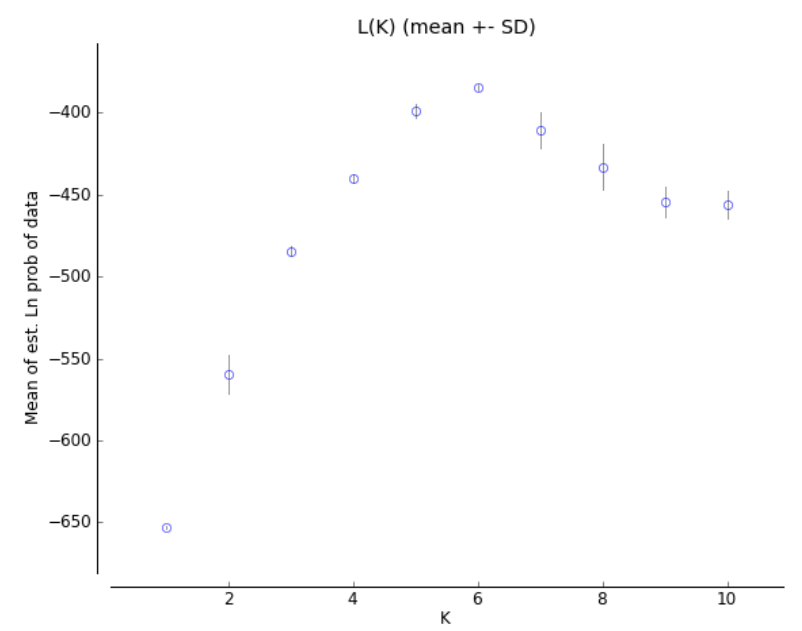

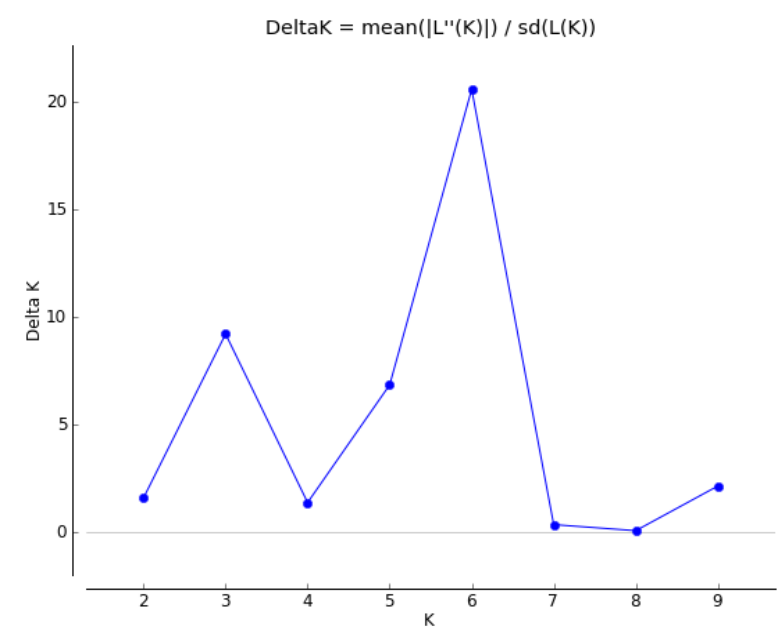

B

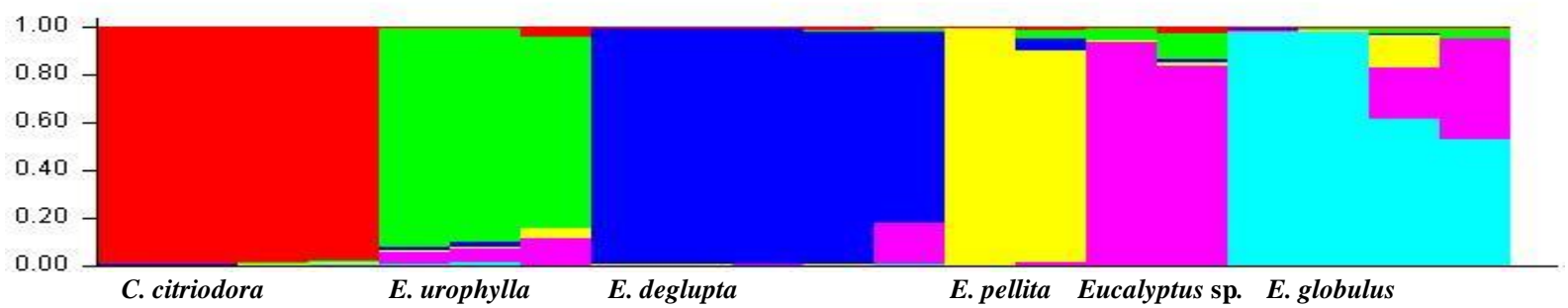

Figure 5. Population structure analysis based on 14 SSR markers. A) Left: The probability of the data Ln P(D) ( \pm SD) (y-axis) against the number of $\mathrm{K}$ clusters (x-axis), and Right: $\Delta \mathrm{K}$ values from the mean log-likelihood probabilities (y-axis) from STRUCTURE runs where inferred clusters (K) ranged from 1 to 10 (x-axis). B) Clusters were from 20 accessions of Corymbia and Eucalyptus in a bar plot. The proportion of each individual ( $\mathrm{y}$-axis) indicate by colors measured the genetic clusters correspond to six main populations ( $\mathrm{x}$-axis).

\section{Implications to conservation management}

The availability of eucalypt cultivated in the KHDTK Bromo Forest can contribute as a reference set that provides marker-based germplasm classification. Moreover, the new accession can easily be compared to this reference set. The 14 SSR markers are potentially used as a marker set for easy application, such as its use for local studies in Sebelas Maret University. This can be very useful for characterizing eucalypt germplasm and enriching eucalypts collections, especially for uncovered novel accession. Furthermore, the 14 SSR markers provided a considerable backup for the mining of germplasm diversity. The molecular data were used for complementing the eucalypt reference set with new additional eucalypt accession and morphological or phenotypic information to characterize the genetic resource and substantial economic benefits, which can also be accommodated. This combination enriches and captures most of the genetic variation within the species of both new and eucalypt accession from other sources to be incorporated in ex-situ conservation in KHDTK Bromo Forest to generate a genetic diversity database for germplasm management and conservation. In the long term, this will contribute to the global eucalypt community to focus on biological investigations by accumulating and compiling data to develop a better biological understanding of eucalypt species, especially species from Indonesia. In addition, the analysis of genetic relationships and distance among
Eucalyptus species can be used as a tool for predicting the potential compatibility of new interspecific combinations to create viable $F_{1}$ hybrids. This showed that the two species of Eucalyptus can be hybridized easily when they belong to the same subgenus/section/series compared to the species from different sections/series and/or subgenera (Potts and Dungey 2004).

In conclusion, the molecular analysis on Corymbia and Eucalyptus detected a low number of alleles per locus and a low level of genetic diversity. Furthermore, the genetic relationships among eucalypts species and the population structure of eucalypts showed the grouping of individuals based on its genus Corymbia and Eucalyptus. This showed that the genetic purity of eucalypts is still maintained.

\section{ACKNOWLEDGEMENTS}

The author would like to gratefully acknowledge Mushlihatun Baroya for technical assistance. This research was funded by the Research and Innovation Consortium funding program to accelerate the handling of corona virus disease 2019 (covid-19) Number: 29/FI/P-COVID19.2B3/ix/2020. The Ministry of Research and Technology/National Research and Innovation Agency and Indonesia Endowment Fund for Education (LPDP), Ministry of Finance Indonesia year 2020. 


\section{REFERENCES}

Abdurakhmonov IY. 2016. Introduction to microsatellites: Basics, trends and highlights. In: Abdurakhmonov IY (ed) Microsatellite Markers. InTech Open, United Kingdom. DOI: 10.5772/66446

Acuna CV, Villalba PV, Garcia M, Pathauer P, Hopp HE, Marcucci Poltri SN. 2012. Microsatellite markers in candidate genes for wood properties and its application in functional diversity assessment in Eucalyptus globulus. Electron J Biotechnol 15 (2): 1-17.

Agrama H, George TL, Salah SF. 2002. Construction of genome map for Eucalyptus camaldulensis DEHN. Silvae Genet 51 (5-6): 201-206.

Arumugasundaram S, Ghosh M, Veerasamy S, Ramasamy Y. 2011. Species discrimination, population structure and linkage disequilibrium in Eucalyptus camaldulensis and Eucalyptus tereticornis using SSR markers. PLoS One 6 (12): e28252. DOI: 10.1371/journal.pone.0028252

Apriyanto D, Kusnandar. 2020. Study of the potential and strategy of developing natural tourism in the forest area with a special purpose (KHDTK) of Mount Bromo. J Belantara 3 (1): 80-88. DOI 10.29303/jbl.v3i1.432 [Indonesian]

Australian Plant Society. 2016. Topic 24: Eucalyptus, Angophora, Corymbia; Family https://www.austplants.com.au/resources/Documents/NorthShoreDocuments/July\%202\%202018\%20Eucalyptus,\%20Angophora, $\% 20$ Corymbia.pdf

Bayly MJ, Rigoult P, Spokevicius A, Ladiges PY, Ades PK, Anderson C, Bossinger G, Merchant A, Udovicic F, Woodrow IE, Tibbits J. 2013 Chloroplast genome analysis of Australian eucalypts- Eucalyptus, Corymbia, Angophora, Allosyncarpia and Stockwellia (Myrtaceae). Mol Phylogenet Evol 69: 704-716. DOI: 10.1016/j. ympev.2013.07.006

Botstein D, White RL, Skolnick M, Davis RW. 1980. Construction of a genetic linkage map in man using restriction fragment length polymorphisms. Am J Hum Genet 32 (3): 314-331.

Bradbury D, Smithson A, Krauss SL. 2013. Signatures of diversifying selection at EST-SSR loci and association with climate in natural Eucalyptus populations. Mol Ecol 22 (20): 5112-5129. DOI: 10.1111/mec. 12463

Brondani RPV, Brondani C, Tarchini R, Grattapaglia D. 1998 Development. characterization and mapping of microsatellite marker in Eucalyptus grandis and E. urophylla. Theor Appl Genet 97: 816827. DOI: $10.1007 / \mathrm{s} 001220050961$

Breed MF, Ottewell KM, Gardner MG, Marklund MHK, Stead MG Harris JBC, Lowe AJ. 2012. Mating system and early viability resistance to habitat fragmentation in a bird-pollinated eucalypt. Heredity 115: 100-107. DOI: 10.1038/hdy.2012.72

Bundock PC, Hayden M, Vaillancourt RE. 2000. Linkage maps of Eucalyptus globulus using RAPD and microsatellite markers. Silvae Genet 49: 223-232.

Burke MK, Long AD. 2012. Perspective: What paths do advantageous alleles take during short-term evolutionary change?. Mol Ecol 21: 4913-4916. DOI: 10.1111/j.1365-294X.2012.05745.x

Chandra A, Tiwari KK, Nagaich D, Dubey N, Kumar S, Roy AK. 2011 Development and characterization of microsatellite markers from tropical forage Stylosanthes species and analysis of genetic variability and cross-species transferability. Genome 54: 1016-1028. DOI: $10.1139 / \mathrm{g} 11-064$

Costa J, Vaillancourt RE, Dorothy AS, Rebecca CJ, Cristina M. 2017. Microsatellite analysis of population structure in Eucalyptus globulus. Genome 60: 770-777. DOI: 10.1139/gen-2016-0218

Earl DA, von Holdt BM. 2012. STRUCTURE HARVESTER: A website and program for visualizing STRUCTURE output and implementing the Evanno method. Conserv Genet Resour 4: 359-361. DOI 10.1007/s12686-011-9548-7

Eckert CG, Samis KE, Lougheed C. 2008. Genetic variation across species' geographical ranges: The central-marginal hypothesis and beyond. Mol Ecol 17: 1170-1188. DOI: 10.1111/j.1365 294X.2007.03659.x

Faria DA, Mamani EM, Pappas MR, Pappas GJ, Grattapaglia DA. 2010. Selected set of EST-derived microsatellites, polymorphic and transferable across 6 species of Eucalyptus. J Hered 101 (4): 512-520. DOI: $10.1093 /$ jhered/esq024

Glaubitz JC, Emebiri LC, Moran GF. 2001. Dinucleotide microsatellites from Eucalyptus sieberi: Inheritance, diversity, and improved scoring of single-base differences. Genome 44 (6): 1041-1045. DOI: $10.1139 / \mathrm{g} 01-106$

Goodine T, Oelgemoller M. 2020. Corymbia citriodora: A valuable resource from Australian flora for the production of fragrances. repellents and bioactive compounds. ChemBioEng Rev 7 (6): 170192. DOI: $10.1002 /$ cben. 202000013

Grattapaglia D, Mamani EMC, Silva-Junior OB, Faria DA. 2015. A novel genome-wide microsatellite resource for species of Eucalyptus with linkage-to-physical correspondence on the reference genome sequence. Mol Ecol Res 15: 437-448. DOI: 10.1111/17550998.12317

He X, Zheng J, Zhou J, He K. 2015. Characterization and comparison of EST-SSRs in Salix, Populus, and Eucalyptus. Tree Genet Genomes 11: 820. DOI: 10.1007 /s11295-014-0820-3

He X, Wang Y, Li F, Weng Q, Li M, Xu LA, Gan S. 2012. Development of 198 novels EST- derived microsatellites in Eucalyptus Myrtaceae. Am J Bot 99 (4): 134-148. DOI: 10.3732/ajb.1100442

Hu LJ, Uchiyama K, Saito Y, Ide Y. 2010. Contrasting patterns of nuclear microsatellite genetic structure of Fraxinus mandshurica var. japonica between northern and southern populations in Japan. J Biogeogr 37: 1131-1143. DOI: 10.1111/j.1365-2699.2010.02275.x

Hudson CJ, Freeman JS, Kullan AR, Petroli CD, Sansaloni CP, Kilian A, Vaillancourt RE. 2012. A reference linkage map for Eucalyptus. BMC Genomics 13: 240. DOI: 10.1186/1471-2164-13-240

Hodel RGJ, Segovia-Salcedo MC, Landis JB, Crowl AA, Sun M, Liu X, Gitzendanner MA, Douglas NA, Germain-Aubrey CC, Chen S, Soltis DE, Soltis PS. 2016. The report of my death was an exaggeration: A review for researchers using microsatellites in the 21st century. Appl Plant Sci 4 (6): apps.1600025. DOI: 10.3732/apps.1600025

Jan C, Dawson DA, Altringham JD, Burke T, Butlin RK. 2012. Development of conserved microsatellite markers of high crossspecies utility in bat species (Vespertilionidae, Chiroptera, Mammalia). Mol Ecol Res 12: 532-548. DOI: 10.1111/j.17550998.2012.03114.x

Júnior S, Garcia JN. 2021. Eucalyptus Subgenus Symphyomyrtus: Sections: Exsertaria. Latoangulatae. and Laerte. Sci Agric 78: e20200173. DOI: 10.1590/1678-992X-2020-0173

Karan M, Evans DS, Reilly D, Schulte K, Wright C, Innes D, Holton TA, Nikles DG, Dickinson GR. 2012. Rapid microsatellite marker development for African mahogany (Khaya senegalensis, Meliaceae) using next-generation sequencing and assessment of its intra-specific genetic diversity. Mol Ecol Res 12: 344-353. DOI: 10.1111/j.17550998.2011.03080.x

Kotrappa H, Hendre PS, Rathinavelu R. 2017. Intra and intergeneric transferable gene-derived orthologous microsatellite markers in Eucalyptus and Corymbia species. J For Res 22 (1): 65-68. DOI: 10.1080/13416979.2016.1262726

Liu K, Muse SV. 2005. PowerMaker: An integrated analysis environment for genetic maker analysis. Bioinformatics 21: 2128-2129. DOI: 10.1093/bioinformatics/bti282

Liu S, Lin Y, Liu X, Luo J. 2016. Genetic diversity and genetic structure of Corymbia citriodora based on SSR analysis. Mol Plant Breed 14: 1923-1929. DOI: 10.13271/j.mpb.014.001923

Liu G, Zhang D, Xie Y, Gu Z, Zhang H. 2017. Genetic differences revealed by genomic-SSRs and EST-SSRs in Eucalyptus species. Eucalypt Sci Tech 34: 1-8. DOI: 10.13987/j.cnki. askj.2017.03.002

Liu G, Xie Y, Zhang D, Chen H. 2018a. Analysis of SSR loci and development of SSR primers in Eucalyptus. J For Res 29: 273-282. DOI: $10.1007 / \mathrm{s} 11676-017-0434-3$

Liu G, Arnold RJ, Xie YJ, Wu ZH. 2018b. Genetic relationships among 40 species of Eucalyptus based on simple sequence repeat markers. J Trop For Sci 30 (3): 402-414. DOI: $10.26525 / \mathrm{jtfs} 2018.30 .3 .402414$

McCulloch ES, Stevens RD. 2011. Rapid development and screening of microsatellite loci for Artibeus lituratus and their utility for six related species within Phyllostomidae. Mol Ecol Res 11: 903-913. DOI: 10.1111/j.1755-0998.2011.03027.x

Mukherjee S, Ramakrishnan U. 2018. Molecular tools for biodiversity conservation. Reson 23: 309-324. DOI: 10.1007/s12045-018-0620-4

Nicolle D. 2019. Classification of the eucalypts (Angophora, Corymbia, and Eucalyptus). Version 4: 1-56.

Nurtjahjaningsih ILG, Widyatmoko AYPBC, Rimbawanto A. 2013. Characterization and application of microsatellite markers in several Eucalyptus species. Jurnal Pemuliaan Tanam Hutan 7 (2): 107-118. [Indonesian]

Ottewell KM, Donnellan SC, Moran GF, Paton DC. 2005. Multiplexed microsatellite markers for the genetic analysis of Eucalyptus 
leucoxylon Myrtaceae and their utility for ecological and breeding studies in other Eucalyptus species. J Heredity 96 (4): 445-451. DOI: 10.1093/jhered/esi057

Padovan A, Webb H, Mazanec R, Grayling P, Bartle J, Foley WJ, Külheim C. 2017. Association genetics of essential oil traits in Eucalyptus loxophleba: Explaining variation in oil yield. Mol Breed 37: 73. DOI: $10.1007 / \mathrm{s} 11032-017-0667-\mathrm{z}$

Parthiban S, Govindaraj P, Senthilkumar S. 2018. Comparison of relative efficiency of genomic SSR and EST-SSR markers in estimating genetic diversity in sugarcane. Biotech 8: 144. DOI: 10.1007/s13205018- 1172-8

Payn KG, William SD, Bernard JHJ, Alexander AM. 2007. Microsatellite diversity and genetic structure of the commercially important tropical tree species Eucalyptus urophylla endemic to seven islands in eastern Indonesia. Tree Genet Genomes 4 (3): 519-530. DOI 10.1007/s11295-007-0128-7

Peakall R, Smouse PE. 2006. GENALEX 6: Genetic analysis in Excel Population genetic software for teaching and research. Mol Ecol Notes 6: 288-295. DOI: 10.1111/j.1471-8286.2005.01155.x

Potts BM, Dungey HS. 2004. Interspecific hybridization of Eucalyptus Key issues for breeders and geneticists. New Forests 27: 115. DOI: 10.1023/A: 1025021324564

Pritchard JK, Stephens M, Donnelly P. 2000. Inference of population structure using multilocus genotype data. Genetics 155: 945-959. DOI: $10.1093 /$ genetics/155.2.945

Rohlf FJ. 2005. NTSYS-pc: Numerical taxonomy and multivariate analysis system, version 2.2. Exeter Software: Setauket, NY.38p.Dc.

Schuster TM, Setaro SD, Tibbits JFG, Batty EL, Fowler RM, McLay TGB, Wilcox S, Ades PK, Bayly MJ. 2018. Chloroplast variation is incongruent with classification of the Australian bloodwood eucalypts (genus Corymbia, family Myrtaceae). PLoS One 13 (4): e0195034. DOI: 10.1371/journal.pone.0195034
Shepherd M, Kasem S, Lee D, Henry R. 2006. Construction of microsatellite linkage maps for Corymbia. Silvae Genet 55: 228-238. DOI: $10.1515 / \mathrm{sg}-2006-0030$

Steane DA, Vaillancourt RE, Russell J, Powell W, Marshall D, Potts BM. 2001. Development and characterisation of microsatellite loci in Eucalyptus globulus (Myrtaceae). Silvae Genet 50 (2): 89-91.

Subashini V, Shanmugapriya A, Yasodha R. 2014. Hybrid purity assessment in Eucalyptus $\mathrm{F}_{1}$ hybrids using microsatellite markers. 3 Biotech 4 (4): 367-373. DOI: 10.1007/s13205-013-0161-1

Sumathi M, Yasodha R. 2014. Microsatellite resources of Eucalyptus: Current status and future perspectives. Bot Stud 55: 73. DOI: 10.1186/s40529-014-0073-3

Sumathi M, Bachpai VKW, Mayavel A, Dasgupta MG, Nagarajan B, Rajasugunasekar D, Sivakumar V, Yasodha R. 2018. Genetic linkage map and QTL identification for adventitious rooting traits in red gum eucalypts. 3 Biotech 8: 242. DOI: 10.1007/s13205-018-1276-1

Ujino T, Kawahara T, Tsumura Y, Nagamitsu T, Yoshimaru H, Ratnam W. 1998. Development and polymorphism of simple sequence repeat DNA markers for Shorea curtisii and other Dipterocarpaceae species. Heredity 81: 422-428. DOI: 10.1046/j.1365-2540.1998.00423.x

Wicaksono RL, Rahmadwiati R, Apriyanto D. 2020. The interaction and dependence of the surrounding community on the special purpose forest area (KHDTK) of Mount Bromo. J Belantara 3 (1): 01-11. DOI: $10.29303 /$ jbl.v3i1.421

Yu Z. 1994. Isolation of Cotton Genomic DNA from Leaf Tissue. http://diyhpl.us/ bryan/irc/protocol-online/protocolcache/cottonyu.html.

Zhou CP, Wang L, Weng QJ, Li FG, Li M, Chen JB, Chen SK, Lv JB, Li DD, Li CR, Gan SM. 2020. Association of microsatellite markers with growth and wood mechanical traits in Eucalyptus cloeziana F. Muell. (Myrtaceae). Ind Crop Prod 154: 112702. DOI: 10.1016/j.indcrop.2020.11270. 